Rigotti, Ana María; "Una joya del Segundo Renacimiento Español en Rosario. La Fuente de los Españoles". Cuadernos del Ciesal, Rosario, UNR, No 20, 2021, pp. 1-29, ISSNe 1853-8827. https://cuadernosdelciesal.unr.edu.ar/index.php/inicio

\title{
Una joya del Segundo Renacimiento Español en Rosario. La Fuente de los Españoles
}

\author{
Ana María Rigotti ${ }^{(*)}$
}

\section{Resumen}

La Fuente de los Españoles, donada por la colectividad con motivo del Segundo Centenario de Rosario en octubre de 1925, inaugurada en el Parque Independencia el 7 de julio de 1929, reúne en sí múltiples historias. La de la cerámica esmaltada, desarrollada por los árabes en la península, transfigurada en sus motivos por influencia italiana y resucitada en el contexto del Segundo Renacimiento Español por el alfar de J. Ruiz de Luna, ganador del concurso para su ejecución. La de la celebración de un falso centenario para publicitar las obras encaradas por el intendente M. Pignetto, ocasión para que las asociaciones de inmigrantes compitan con las instituciones de las familias tradicionales. La de la curiosa convergencia del nacionalismo estético local con la reivindicación espiritual de la hispanidad uno de cuyos principales cultores, $R$. de Maeztu, estuvo presente en la inauguración. La de los parques urbanos como signo de civilidad donde convergen higienismo, nuevas prácticas sociales y pedagogía del gusto. Finalmente las desventuras de la pieza, considerada como la más grandiosa del mundo en su tipo, hasta su pronta reinauguración.

Palabras clave: Parque; Fuente; Cerámica; Talavera; Inmigrantes; hispanidad; Rosario.

\section{A jewel of the Second Spanish Renaissance in Rosario. The Fountain of the Spaniards}

\begin{abstract}
The Fuente de los Españoles, a gift of the Spanish community on the Second Centennial of Rosario in October 1925, inaugurated in the Parque Independencia on July 7, 1929, gathers multiple histories. That of glazed ceramics developed by the Arabs in the peninsula, transfigured in its motifs by Italian influence and resurrected in the context of the Second Spanish Renaissance by the alfar of J. Ruiz de Luna, winner of the competition for its execution. The celebration of a false centennial to publicize the works undertaken by Mayor M. Pignetto, an occasion for immigrant associations to compete with the institutions of traditional families. The curious convergence of local aesthetic nationalism with the spiritual vindication of the "hispanidad", one of whose main cultists, $R$. de Maeztu, was present at the inauguration. The story of urban parks as a sign of civility where hygienism, new social practices and the pedagogy of taste converge. Finally the misadventures of the fountain, considered the greatest in the world of its kind, until its early reopening.
\end{abstract}

Key Words: Park; Fountain; Ceramics; Talavera; Inmigrants; Hispanidad; Rosario.

\footnotetext{
${ }^{(*)}$ Doctora en Arquitectura (Universidad Nacional de Rosario). Miembro del Consejo de Investigaciones de la Universidad Nacional de Rosario (CURDUIR-UNR-CONICET), Argentina. Mail: amirigotti@gmail.com ORCID: https://orcid.org/ 0000-0002-5340$\underline{109 X}$
} 
"Una joya del Segundo Renacimiento Español en Rosario. La Fuente de los Españoles"

\section{Una joya del Segundo Renacimiento Español en Rosario. La Fuente de los Españoles}

\section{Introducción}

De Ricardo Falcón aprendí tantas cosas. Quizás la principal haya sido comprender hasta qué punto política, sociedad, objetos de diseño y discusiones sobre lo bello (y lo bueno) están tan intrínsecamente entretejidos que resultaba inútil segregarlos. Fue él quien me ayudó a conferir dignidad no solo a la historia de un barrio perdido como canevá e índice de la disputa social, sino a la arquitectura y al arte como productos políticos que merecían ser rescatados del limbo de los artefactos ingenuamente contemplados, venerados e incluso preservados, aunque estuvieran empapados en sangre. Así hoy, la Fuente de los Españoles se niega a ser solo fruto de cándidos festejos provincianos. Resultado de artimañas políticas, de juegos de poder entre los miembros exitosos de una colectividad, de las pasiones de españoles ahítos frente a la irremediable decadencia del imperio, del revival de un frágil Segundo Renacimiento Español, la próxima reinauguración de la fuente nos convoca a escarbar en sus condiciones de existencia.

\section{Algunas palabras clave}

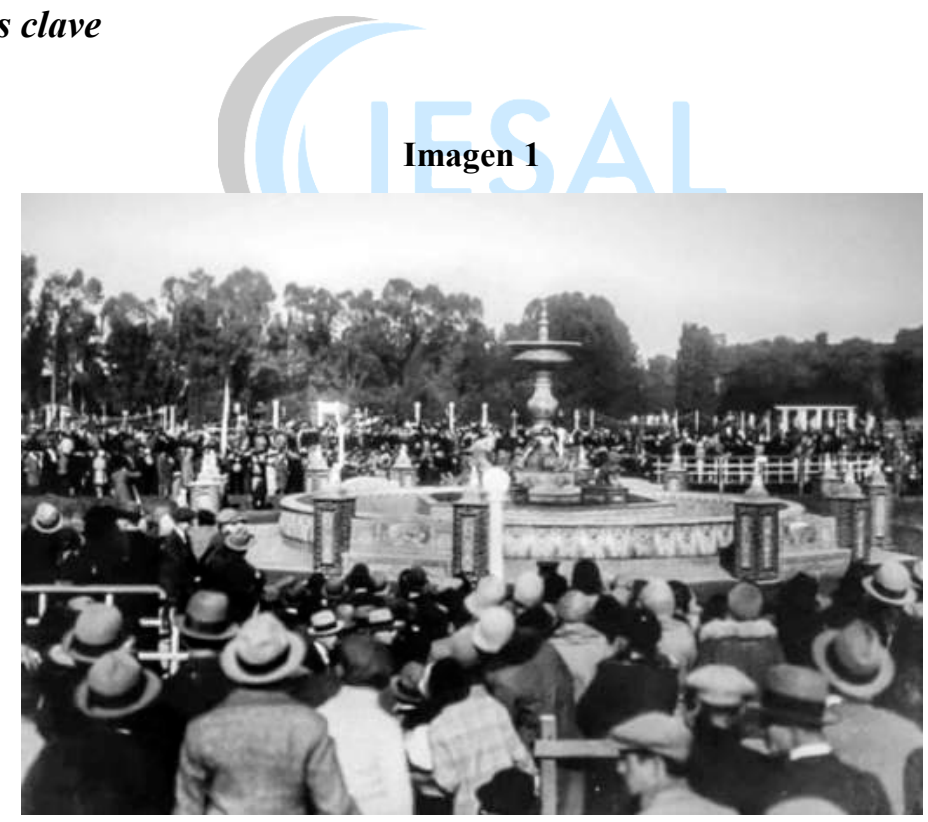

Fuente: Día de la inauguración

Hace más de noventa años, se inauguraba en El Rosedal del Parque Independencia de Rosario, la Fuente de los Españoles. Remozada y brillante, la podremos volver a ver, tocar y apreciar luego de más de cuatro años de laboriosa y costosa restauración. Porque "la fuente de cerámica más grandiosa del mundo, un triunfo del arte español” según palabras del periodista Santiago 


\section{Ana María Rigotti}

Camarasa (1928), ${ }^{1}$ obra del alfar de Juan Ruiz de Luna, artífice del renacimiento de la mayólica artística de Talavera de la Reina, no sólo estaba deslucida, con piezas rotas y faltantes, sino floja de cimientos. Fue donada el 4 de octubre de 1925, como broche de oro de la celebración del ficticio Segundo Centenario de una ciudad sin padre ni nacimiento reconocido. Concebida para dar marco a la gestión de nuestro intendente higienista, Manuel Pignetto, este festejo fue la ocasión para impulsar un nuevo sentido, sportivo y popular, de nuestro gran parque, colocando la piedra fundamental del Estadio Municipal. La donación de la fuente fue gestada por una comisión de inmigrantes españoles notables y enriquecidos, encabezada por el Dr. Tomás Sierra cónsul en nuestra ciudad, ${ }^{2}$ con el explícito propósito de que fuera expresión de un arte popular. Exaltando la relevancia que el agua tuvo como celebración de la naturaleza en la cultura mudéjar, buscaba engalanar el tesoro de una ciudad que pugnaba por incorporar los más altos índices de espacios verdes en su desarrollo urbano. La fuente fue inaugurada casi cuatro años más tarde, el 7 de julio de 1929, con la presencia del filósofo y literato Ramiro de Maeztu, entonces embajador plenipotenciario en Argentina, subrayando a través de su personalidad y sus prédicas este hito de "hispanidad" (Martini, 2017; González Calleja, 2007).

En esta breve introducción se incluyen una serie de palabras que resultan claves para entender no sólo la existencia, sino la relevancia de esta pieza: parque, fuente, cerámica, Talavera, inmigrantes, hispanidad, Rosario. Original en su concepción, bella y casi única en el mundo, los rosarinos hemos hecho de ella desde un ingenioso dispositivo para jugar a las escondidas hasta un fotogénico escenario para bodas y celebraciones. Interesa compartir el asombro de descubrir las múltiples capas de la excepcionalidad de este rincón de la ciudad, que poseemos y gozamos con indiferencia, y en el que se reúnen y enredan tantos hilos de nuestra historia.

Como afirma Fernando Martínez Nespral (2018), los azulejos, y en este caso más complejo la Fuente de los Españoles en Rosario, remiten a una larga y tortuosa historia de conquistas y migraciones, exilios y conversiones, procesos interculturales e hibridaciones, vencedores y vencidos. Son muchas las conmociones culturales que están presentes en ella. La llegada a la Península Ibérica en el año 711, a causa de una fractura entre dos facciones de visigodos, de bereberes recién convertidos al Islam con la consecuente incorporación de un amplio abanico de expresiones culturales: desde el agua como componente arquitectónico de las grandes residencias, hasta la cerámica esmaltada como revestimiento muros y fuentes. La larga reconquista cristiana, que no casualmente comenzó en Toledo y culminó cuatro siglos más tarde

\footnotetext{
${ }^{1}$ Santiago Camarasa (1895-1957) fue un industrial, impresor y periodista, ardiente promotor de la conservación y restauración del patrimonio cultural, en particular de la ciudad de Toledo, que se había expresado públicamente a favor del régimen de Miguel Primo de Rivera.

${ }^{2}$ La comisión estaba integrada por Odilio Estévez, Victor Echeverría, Emilio Rey, Manuel Alvarez, Manuel Ordoñez, Miguel Monserrat, Benito Rorviso, Manuel Giménez, Ricardo Ortega, Jose Valenzuela, Juan B. Torres, Sebastián Gana y Domingo Bosch. Luego se sumó Angel García.
} 
con la caída de Granada en 1492, año del "descubrimiento" de nuestra América y con ello de una secuencia de migraciones al Sur que promovieron tanto la hibridación mudéjar (mano de obra árabe al gusto de los cristianos) como la criolla en territorios de ultramar.

Los comienzos del siglo XVI también fueron escenario de la expansión de las artes y las humanidades en el norte italiano, propiciando viajes de formación y migraciones de expertos que sacudieron fuertemente el ámbito de la producción de cerámica en ambos sentidos: incorporando la palabra maiolica al italiano con referencia a Mallorca o Málaga, y provocando en España transformaciones técnicas e iconográficas. Se pasó de la ornamentación basada en paños de patrones geométricos repetitivos enmarcados por cenefas que simulaban, simplificando, el efecto del alicatado, a planos pintados por piezas conformando un cuadro mayor, con escenas inspiradas en pinturas con temas religiosos o heráldicos. La tortuosa historia de la mayólica nos remite, cinco siglos más tarde, a ese 1898 en que España debió conceder la independencia a Cuba y ceder a Estados Unidos Puerto Rico, Filipinas y Guam, señalando su declive definitivo como potencia imperial y estimulando un movimiento filosófico y literario conocido como la Generación del 98 que reflexionó sobre la posibilidad de otro tipo de vínculo -espiritual-, con las antiguas colonias: el hispanoamericanismo.

Esto último ocurría mientras poblaciones de ignotos parajes campesinos, hambreadas, sometidas a levas forzosas y a los avances de una nueva lógica capitalista en expansión, emigraban a las Américas. Con suerte desigual, se aglutinaban en asociaciones de socorros mutuos y, en los casos más exitosos, conformaban poderosas entidades capaces de reivindicar tradiciones "propias" como prueba de una lograda integración económica, social y cultural en sus lugares de acogida; integración a inestables hervideros de extraños como era, entonces, Rosario. La ciudad había pasado de ser un mero recodo en el Camino Real, con una capillita de barro y paja que congregaba en su entorno ranchos endebles sin regla ni concierto, a convertirse en un próspero puerto y centro económico que, en su delirio de grandeza y tambaleante prosperidad, declaraba a través de un censo cuestionado haber alcanzado los 407.000 habitantes y procuraba dejar atrás las oscuras circunstancias de su nacimiento, celebrando con buques de guerra, visita presidencial, ópera, cena de gala, bailes y fuegos artificiales el supuesto aniversario de su fundación.

\section{El Rosario festeja}

Comencemos el relato con Rosario y su infructuosa búsqueda de identidad. Fueron múltiples los intentos para superar su condición de ciudad no deseada ni imaginada, sin protección ni padrinazgo (Megías et al., 2014). Es comprensible, entonces, que se aferrara a un primer y 


\section{Ana María Rigotti}

mínimo gesto de reconocimiento burocrático, la fijación de jurisdicción para uno de los dos alcaldes de Santa Hermandad nombrado desde el primer día de 1725 por el cabildo santafesino para resolver conflictos en los pagos de "Coronda y los Arroyos" que comprendía desde el sur de la ciudad de Santa Fe al Arroyo del Medio. ${ }^{3}$ Se trataba de un territorio impreciso, apenas poblado, que estaba sufriendo procesos de cambio con el traslado de algunas poblaciones de indios reducidos a cargo de los franciscanos. El edicto no hacía referencia a población alguna pero, sólo cinco años más tarde, el clero resolvía el establecimiento de un curato con asiento en un caserío discreto y disperso organizado alrededor de una capilla (Barriera, 2013).

La conciencia de la fragilidad de esta evocación de un "nacimiento" era plena. Al Segundo Centenario se lo sancionó mediante una ordenanza del Concejo Deliberante y, dudando respecto al día adecuado, se optó por un supuesto 4 de octubre en coincidencia con el día de la Virgen del Rosario como patrona de la ciudad, hasta ese momento celebrado el primer domingo de octubre (Alvarez, 1981, p. 53-55). Acaban de sortearse con dificultad los años duros de la Gran Guerra con su secuencia de revueltas sociales, desocupación y parálisis del flujo migratorio. El municipio había debido comprometer su erario en una serie de políticas sociales, entre ellas la construcción de más de mil unidades de viviendas formando cuatro barrios en la periferia. Apenas un $40 \%$ de la población era nativa lo que aumentaba la inestabilidad política, económica y cultural. Sin embargo, casi el $90 \%$ de la población, decía el cuestionado censo, ya contaba con agua corriente y el tráfico de ultramar aumentaba a pesar de las dificultades asociadas a la nacionalización del puerto. Y la ciudad decidió celebrarse.

El intendente Pignetto construyó esta operación para promover sus iniciativas más audaces. Se llamó a un nuevo concurso para la construcción del Monumento a la Bandera a través del cual Rosario pudiera reclamar un lugar en la historia heroica de la patria. En el marco de los festejos, se colocaron las piedras fundamentales del edificio del Correo Central, de la Clínica del Trabajo, de una nueva sala para el Hospital Rosario (luego Clemente Alvarez), del Museo de Ciencias, del mencionado Stadium Municipal, y de la estación terminal del Ferrocarril Central Argentino luego fuertemente resistida. Nombrado por el gobernador radical Ricardo Aldao, la fluida relación del intendente con el gobierno nacional se tradujo en la presencia del presidente Marcelo T. de Alvear que llegó en tren escoltado por dos endebles aeroplanos. Luego de estar presente en el Te Deum, Alvear inauguró el Camarín de la Virgen, en el subsuelo de la Catedral, realizado por el arquitecto siciliano José Gerbino.

Los festejos prosiguiendo con un banquete de gala en la Jefatura de Policía y la presentación de la ópera Raquel en el actual teatro El Círculo. Era una obra de Tomás Breton, autor de la

\footnotetext{
${ }^{3}$ Desde entonces y hasta que Rosario fuera designada villa en 1823, el Pago de los Arroyos - distrito dependiente de la ciudad de Santa Fe y desde 1815 de la Provincia- estuvo sujeto a la jurisdicción de un Alcalde de la Hermandad designado por el cabildo santafesino.
} 
zarzuela La verbena de la paloma, lo que revela el carácter popular que pretendió darse a las celebraciones. Durante diez días se sucedieron desfiles de rodados, torneos, conciertos, bailes, reparto de ropas y víveres en los distintos barrios. Y las principales instituciones y colectividades se hicieron presentes con donaciones que, no casualmente, tenían como destino un Parque Independencia en plena renovación. El Jockey Club ofreció la Diana para El Rosedal, los franceses otra escultura para el futuro Jardín Francés, los belgas y los españoles, sendas fuentes.

Los ibéricos habían formado una comisión especial con el objetivo de "exteriorizar a este emporio de riquezas y de trabajo, donde muchos hemos construido nuestros hogares, todo el intenso afecto y la sincera gratitud (...) sin exclusión de las que ejercitamos en provecho moral de la lejana patria" (El Eco de España, 1928). Estaba encabezada por Odilio Estevez, propietario de Yerba 43 y de la casa frente a la Plaza 25 de Mayo que había remodelado el mencionado José Gerbino y que hoy es el Museo Municipal de Arte Decorativo. Formado en la Academia di Belle Arti de Palermo, Gerbino había ganado el Premio de Roma de 1906 y era autor, junto con Alfredo Guido, de un bargueño estilo calchaquí acreedor de la Medalla de oro del Primer Salón Nacional de Artes Decorativas de 1918. La casa de tres patios, que había pertenecido a la familia Ibarlucea, venía de ser replanteada según las tradiciones ibéricas siguiendo la voluntad del matrimonio Estevez; cobijaba obras y objetos de arte adquiridos en Europa con el asesoramiento de Antonio Pérez Valiente de Moctezuma, editor de la revista Plus Ultra.

\section{Hispanidad, entre la moda y la tragedia}

Estos detalles buscan retratar un clima de época singular que enlazaba Argentina y España, y que ayuda a entender las elecciones y alianzas tras la existencia misma de la Fuente de los Españoles. Nos referimos al singular maridaje en el que se fraguaban ciertas iniciativas nacionalistas en el arte argentino, recurriendo a filiaciones no solo indígenas, sino coloniales e incluso con referencias directas a la raigambre española influidas por el brillo de la Generación del 98. Lo español estuvo en la ópera elegida para celebrar el Segundo Centenario de Rosario, en la pompa con que en marzo del año siguiente se festejó la visita de Ramón Franco luego de cruzar el Atlántico en su avión Plus Ultra y en el consumo de la revista del mismo nombre. Separata "artística" de la popular Caras y Caretas entre 1916 y 1930, incluía en su logo la divisa monárquica española sobreentendida como signo de linaje. Eran tiempos de crecimiento 


\section{Ana María Rigotti}

de las corrientes reaccionarias en el mundo: 1922 la marcha sobre Roma de Mussolini, 1923 el ascenso de Primo de Rivera en España. ${ }^{4}$

España era connotada en las apelaciones a la espiritualidad, los patios andaluces, los uniformes militares que remedaban los del ejército de Primo de Rivera, y en el ambiguo estilo colonial de las nuevas residencias de intelectuales argentinos: Ricardo Rojas, Enrique Larreta, Martín Noel, Rogelio Yrurtia en Buenos Aires, Juan Zorrilla de San Martín en Montevideo. En una suerte de empaque aristocrático, un Segundo Renacimiento Español (del cual nuestra fuente es digno ejemplo) se enlazaba con lo popular y lo gauchesco como "noble tradición”. Estaban presentes en el mobiliario, los objetos de adorno, las escenas "sugestivas" de relatos y pinturas presentadas en los Salones Nacionales. Intelectuales, familias de estirpe e inmigrantes enriquecidos resultaban aunados en lo que la misma Plus Ultra calificaba como "reacción tradicionalista". Huían de la realidad plebeya e inquietante de la gran ciudad y de los efectos "desnaturalizantes" de la inmigración. De este proceso servía de vidriera la revista. Intercalaba retratos de miembros de la clase alta nacional con pequeños poemas y relatos, noticias del exterior con destacable interés por las casas reales, semblanzas de un turismo cultural europeo con marcado énfasis en España, y del turismo "patriótico" que osaba desplazarse desde la selva Tucumana al Nihuil.

Lo que en el ámbito político estuvo asociado a disputas cruentas en torno a lo nacional, asociado a posturas anti inmigratorias, antiliberales e incluso reaccionarias, tuvo también una faceta más liviana vinculada a una moda: "El estilo español, es decir, el llamado estilo colonial esta hoy de moda entre nosotros. La influencia de la arquitectura hispana con sus clásicas líneas, ha encontrado no solo en Buenos Aires sino en muchas ciudades del interior, pueblos y playas de veraneo, entusiastas admiradores" (Plus Ultra, 1929). Así presentaba en su número de octubre de 1929 imágenes de las residencias ya nombradas que incluían, como "rincón fragante", fuentes interiores revestidas en mayólicas; también se incorporaban las fotografías de algunos edificios públicos "en estilo": el Banco de Boston, el Teatro Cervantes. En números anteriores Plus Ultra había reproducido el proyecto ganador para el Palacio de la Caja Nacional de Ahorro postal de Francisco Squirru y Angel Croce Mujica (Plus Ultra, 1925a), los muebles incaicos del Dr. Horacio Carrillo para la legación argentina en La Paz (Suero, 1925), el proyecto de Martín Noel para una nueva facultad de humanidades (de Amador, 1926) y el Camarín de la Virgen en Rosario "en el más puro estilo colonial, con detalles similares al altar monumental de la capilla interior de los jesuitas en Córdoba" dos meses luego de inaugurado (Plus Ultra, 1925b).

\footnotetext{
${ }^{4}$ Miguel Primo de Rivera, militar, descendiente de la aristocracia terrateniente, encabezó un golpe de estado con el visto bueno del rey Alfonso XIII el 13 setiembre 1923. Antiliberal, autoritario, a favor de la permanencia de España en Marruecos, suspendió la Constitución, estableció una asamblea consultiva de corte corporativista y su gestión se caracterizó tanto por la represión del movimiento anarco-sindicalista como por la obra pública. Dimitió el 28 enero de 1930 al perder favor del rey.
} 


\section{Imagen 2}

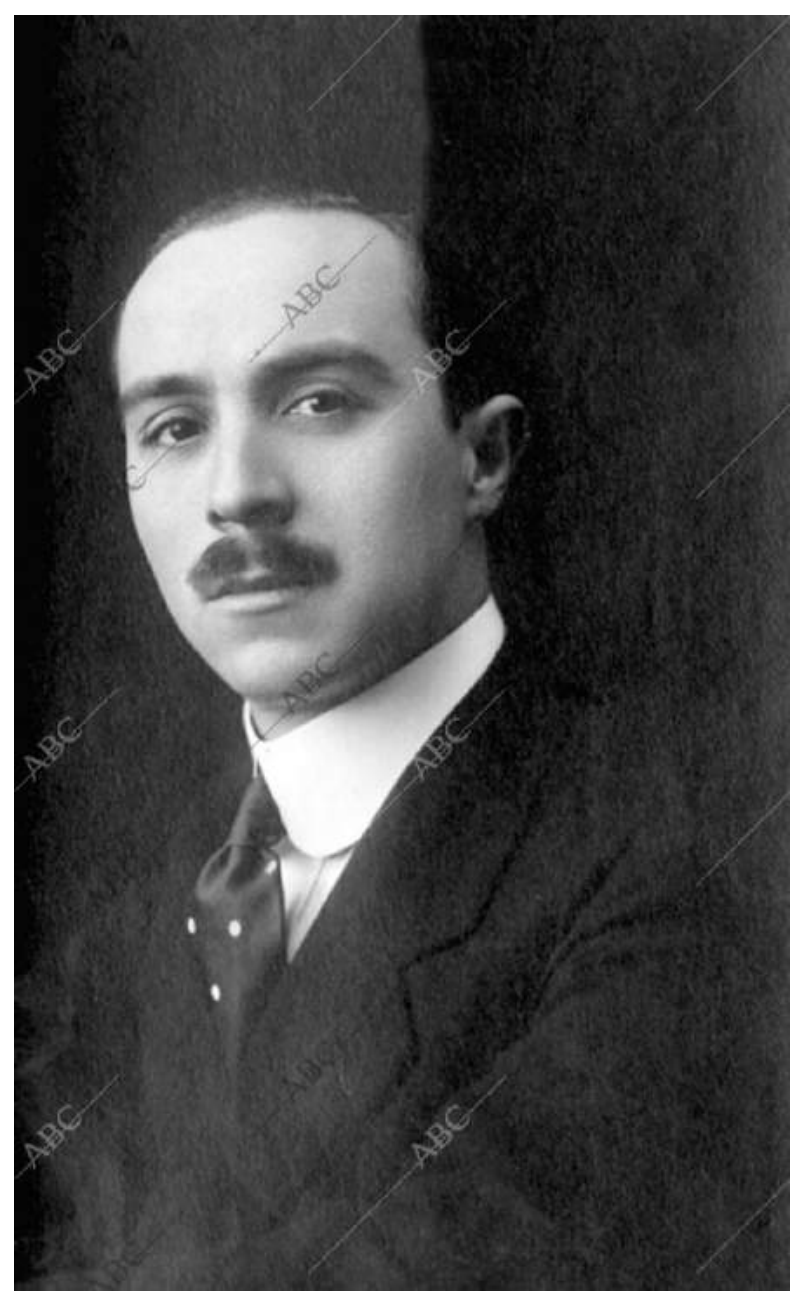

Fuente: Foto de Tomás Sierra, cónsul de Rosario, del archivo del Diario ABC 29 de febrero 1916.

Podemos otorgar, entonces, otras implicancias a la decisión del cónsul Tomás Sierra. En nombre de la incipiente elite de la colectividad española decidió que la ofrenda debía ser una fuente en representación de las artes populares, y no una escultura, como la de los franceses, expresión de los parámetros pretendidamente universales del arte académico o del talento de un artista: "la forma ornamental artística popular por excelencia, emblema de la Madre Patria, y no la obra de un solitario escultor o pintor, sino la obra de muchos pintores y escultores anónimos" (Conde 2020). Recordemos, además, que el agua en la tradición de Al-Andalus implicaba referencias al paraíso e inspiración poética asociada al movimiento, la frescura y, en el caso de las fuentes revestidas en mayólica, la sonoridad de su entrechocarse contra la superficie vitrificada. 


\section{Imagen 3}

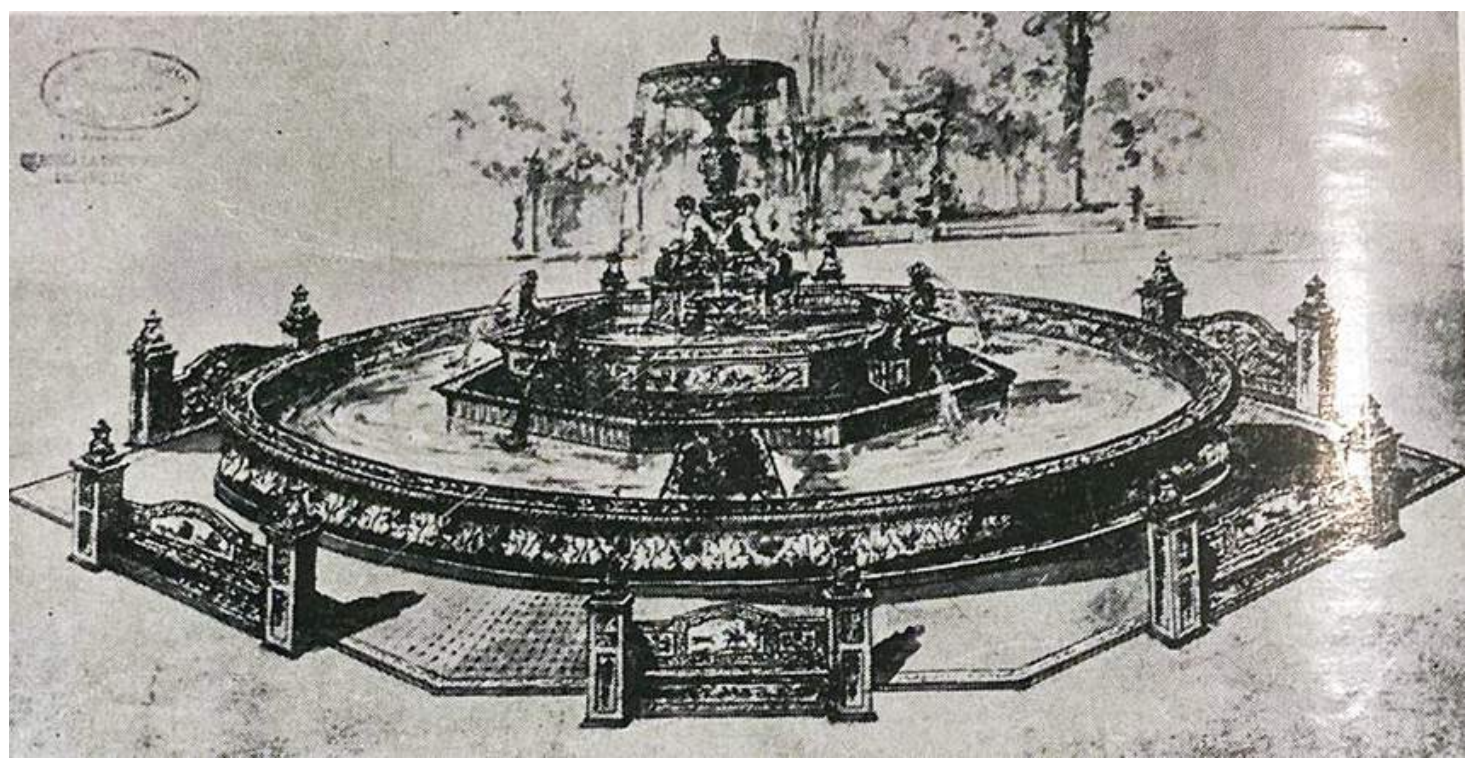

Fuente: Dibujo de la fuente reproducido en El Eco de España el 12 de octubre de 1928 para impulsar la recaudación de fondos.

Claramente imbuido de las corrientes de "recuperación" de la cerámica tradicional, Sierra propuso una compulsa entre las tres regiones que habían contribuido al apogeo de la mayólica española en el siglo XVI. Invitó a enviar proyectos a fábricas de Manises (Valencia), Triana (Sevilla) y Talavera de la Reina (Toledo). En 1926 eligió la propuesta del alfar Nuestra Señora del Prado de Juan Ruiz de Luna "por la elegancia que caracteriza a esta cerámica de Talavera y las características monumentales de proyecto cuyas características llaman poderosamente la atención a los entendidos" (Conde, 2020).

Pero antes de avanzar en las características de la obra y del lugar de la cerámica en este Segundo Renacimiento Español, detengámonos en circunstancias de la inauguración de la fuente con la presencia del nuevo embajador Ramiro de Maeztu, ${ }^{5}$ que por razones logísticas no pudo realizarse el Día de la Raza de 1928 Colaborador habitual de periódicos locales como corresponsal en Londres del diario La Prensa desde 1905, de Maeztu era en esos momentos representante de un tradicionalismo radical condensado en el concepto de "hispanidad". Reivindicaba la misión ecuménica de los factores espirituales de la raza, con el idioma y el catolicismo como fuerzas aglutinantes, asociándolos al mito de lo latino y de una arcadia de

\footnotetext{
${ }^{5}$ Ramiro de Maeztu (1874-1936) ensayista, novelista, crítico literario y teórico político de padre cubano y madre inglesa. Luego de una larga estadía como corresponsal en Inglaterra y de colaboraciones con el diario liberal $\mathrm{El} \mathrm{Sol}$, migró a posiciones reaccionarias ingresando en la Unión Patriótica lo que le valió su nombramiento como embajador plenipotenciario en Argentina entre febrero de 1928 y febrero de 1930. A su retorno y ya instaurada la Segunda República, dirigió la revista Acción Española, órgano del Unión Monárquica Nacional, en 1934 publicó Defensa de la Hispanidad, concepto acuñado por el jesuita Zacarías de Vizcarra con el cual había entablado amistad en Argentina y que constituía un alegato a favor de la monarquía y la tradición católica. Apenas iniciada la guerra civil, fue detenido y el 29 de octubre de 1936 junto con otros 31 prisioneros, sacados de la cárcel de Ventas y fusilados en el cementerio de Aravaca.
} 
“Una joya del Segundo Renacimiento Español en Rosario. La Fuente de los Españoles"

solidaridad social destruida por un liberalismo que rastreaba hasta los Borbones. Justificaba en España, como próximamente en Argentina, la intervención militar frente a la "corrupción democrática" y la amenaza "disolvente" del anarcosindicalismo.

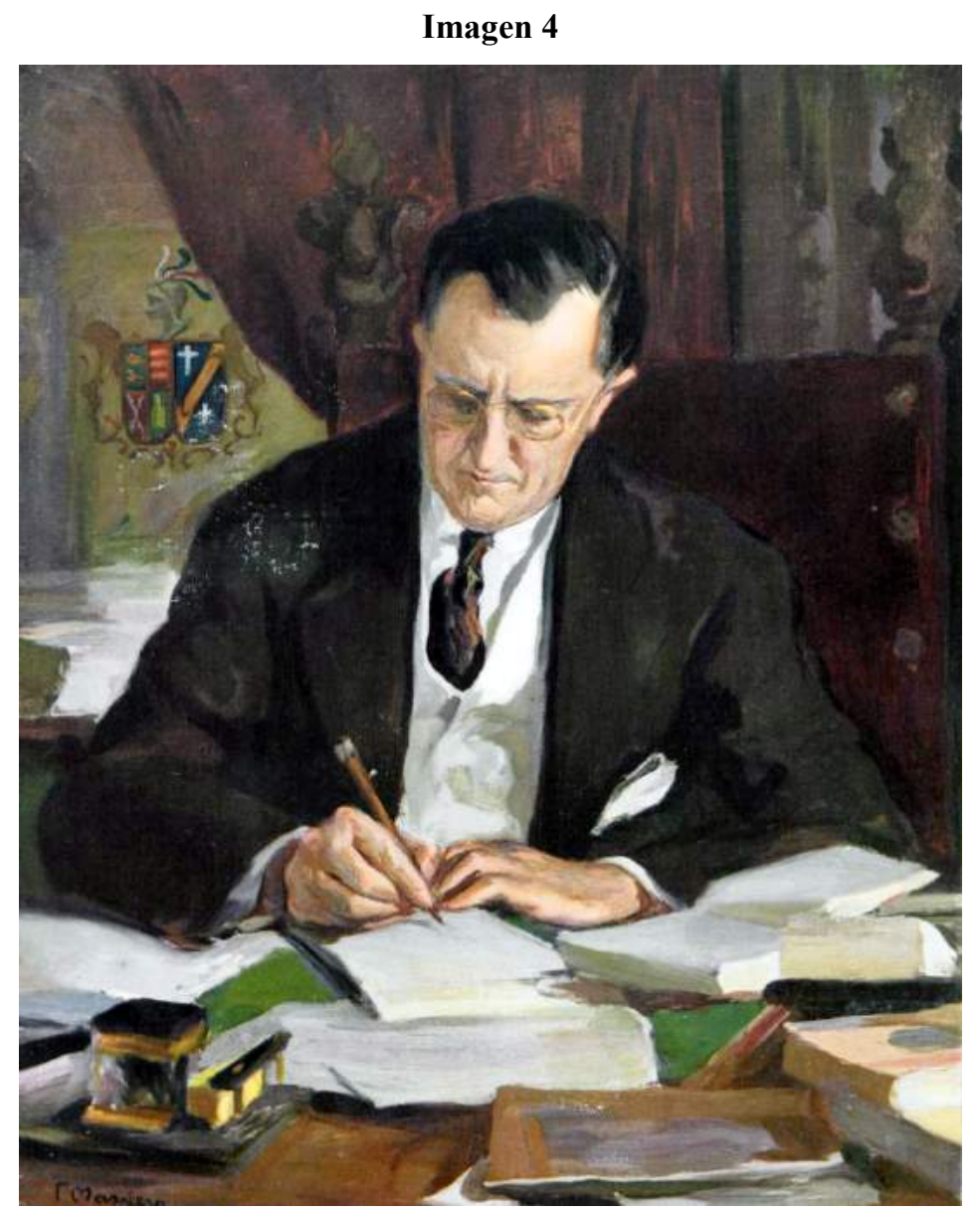

Fuente: Oleo de Rodrigo Maeztu por F. Masriera en Plus Ultra 14.1929=Nr. 162,11 .

Ya radicado en Argentina, su relevancia como intelectual no sólo le permitió multiplicar sus presentaciones públicas, participar activamente en la revista Criterio e inclusive recibir, a poco de ser nombrado embajador, una cálida bienvenida de la pluma nada menos que de Alberto Gerchunoff (1929), miembro del partido socialista y futuro presidente de la asociación antifascista AIAPE. ${ }^{6} \mathrm{Su}$ actividad política fue intensa, creó uniones patrióticas entre los inmigrantes en apoyo al régimen de Primo de Rivera y tuvo destacada influencia en el

\footnotetext{
${ }^{6}$ Gerchunoff (1929) califica a Ramiro de Maeztu de excepcional representante de la transformación de la cultura española iniciada en el 98 y celebra el homenaje que se nos habría hecho al nombrar como diplomático a un hombre de letras con capacidad de incidir con mayor eficacia en la "compenetración y difusión de los elementos esenciales de la cultura de un pueblo". Más que un profeta sombrío. lo considera un enderezador de la conciencia colectiva, un analista que se ha vuelto hacia las figuras simbólicas de su raza, en particular el Quijote, en procura de encontrar en ella la urdimbre de ocultas leyes históricas.
} 


\section{Ana María Rigotti}

nacionalismo conservador local y en el inminente golpe del 6 de septiembre de 1930, si bien ya había retornado a España a comienzos de ese año.

\section{De parques y fuentes}

De la importancia adjudicada por este pensamiento conservador a las fuentes como tema artístico en la composición de los parques y jardines públicos, también nos ilustra la revista Plus Ultra: "Grandes obras de arte influyen en el espíritu de las masas tendiendo a su mejoración [...] en una cotidiana e invisible acción secreta sobre el alma de los transeúntes las cuales sin saber darse cuenta concluyen por enriquecerse con un sentimiento de idealidad muy superior a su mezquina capacidad intelectual". Al igual que las huidas melancólicas a un pasado presuntamente puro, son un recurso "para defenderse de las impurezas de la vida en común [...] En nuestro tiempo de estrépito, de orgia de velocidades, el ademán sereno y puro cobra sentido" (Salverría, 1926).

El parque público se había consolidado a mediados del siglo XIX como equipamiento sustancial de la gran ciudad. No sólo pretendía compensar los males ambientales urbanos sino que, provisto de programas complejos, el parque se había convertido en escenario indispensable de nuevas formas de recreo y sociabilidad. Se imponía el modelo francés madurado a través de los proyectos de Jean-Charles Alphand. Remedo de naturaleza modulada desde pautas estéticas, el diseño del parque se componía de una sucesión de escenas variadas y curiosas, en general asociadas a lo exótico y definidas por una serie de motivos arquitectónicos (folies), naturales (lomas, cavernas, cascadas y lagos) o artísticas en el registro escultórico. La unidad de la composición estaba garantizada por la pureza de líneas en el modelado del terreno y en el trazado de las vías de tránsito pensadas para el encuentro social. El detalle se hacía presente en los efectos de amplitud y la cuidada superposición de planos conformados por distintas especies arbóreas que se desplegaban al avanzar por los sinuosos senderos peatonales.

Elemento central de las teorías higienistas, contrapunto al caos estético y la congestión funcional de ciudades signadas por el progreso material, el parque perseguía el equilibrio físico y psíquico de la población, pero también la extensión de la planta urbana. En Argentina y a pesar de la baja densidad de nuestras ciudades, la construcción de parques fue promovida por Domingo Sarmiento que logró concretar la primera versión el 3 de Febrero en 1875 sobre las tierras del caserón de Manuel de Rosas. Y fueron varios los expertos franceses contratados para diseñarlos. El primero, Carlos Thays, discípulo de Édouard André, fue convocado en 1889 por el empresario inmobiliario Miguel Crisol para la ejecución del ahora Parque Sarmiento en la ciudad de Córdoba. Luego de ganar el concurso para la Dirección de Parques y Paseos de 
Buenos Aires, se quedó en el país y fue responsable del diseño de 69 plazas y paseos, además de otros 16 en las provincias y varios en Uruguay. Se le atribuye el diseño del Parque de Independencia de Rosario.

A fines del siglo XIX, el porcentaje de "espacios verdes" se había convertido en un parámetro ampliamente aceptado de modernidad y Rosario se debía uno. El proyecto inicial fue del intendente Alberto Paz en 1897 y hubiera abarcado 18 manzanas. Frustrado en su tratamiento político por Santa Fe, lo reeditó el intendente Luis Lamas. Con planos firmados por el ingeniero Héctor Thedy, las tierras comenzaron a expropiarse el 10 agosto 1900 y el Parque de la Independencia se inauguró con fuegos artificiales el 1 de enero de 1902.

A diferencia de otros grandes parques urbanos, no había en este caso preexistencias topográficas que justificaran la localización, salvo su ubicación estratégica en el cruce de la primera ronda de bulevares (los actuales Oroño y Av. Pellegrini) y a continuación de la gran Plaza Independencia. En un primer momento fue escenario exclusivo de la vida social de las clases acomodadas. Estaba cercado y no casualmente el Jockey Club se había fundado en setiembre de 1901 recibiendo en donación la parcela para instalar su hipódromo que inauguró a fines de 1902 con una carrera a la que habrían concurrido 3000 personas. Actualmente el Parque Independencia cuenta con 126 ha, onerosamente acumuladas a través de la expropiación de tierras privadas cuyo precio fue aumentando a medida que se concretaban las obras.

En el Parque Independencia todo fue exotismo: las especies vegetales, los animales del zoológico, los aparatos para el recreo infantil, la hípica, el remo. No hay dudas de la operación técnica y estética que supuso la construcción de este paisaje opuesto a la pampa, a su flora y a su fauna. El parque promovía la superación de la pasividad de los cuerpos femeninos a través de caminatas, el sport como práctica saludable y como espectáculo y, sobre todo, la educación del gusto en una sociedad áspera y aluvional. A ello contribuían los distintos recintos en los que se fue subdividiendo su extensión, cada uno concebido como una unidad geométrica peculiar. Se destacaba El Rosedal, ejecutado en 1915 con un trazado en parterres que reforzaba el efecto de las floraciones en distintos colores y fuerte perfume, sumando la "montañita" con su templete, el estanque con su puente, una pérgola para las especies trepadoras que aseguraba el descanso a la sombra con la mirada haciendo foco en el agua. Allí habría de instalarse la Diana donada por el Jockey Club y fue el lugar donde el cónsul Sierra, junto al intendente Pignetto, decidieron colocar la futura fuente. No debemos olvidar que, hasta 1932, El Rosedal estuvo cercado, con acceso restringido en días diferenciados para hombres y mujeres, pagando una entrada, y guardando buen aspecto y vestuario. 


\section{Ana María Rigotti}

\section{Imagen 5}

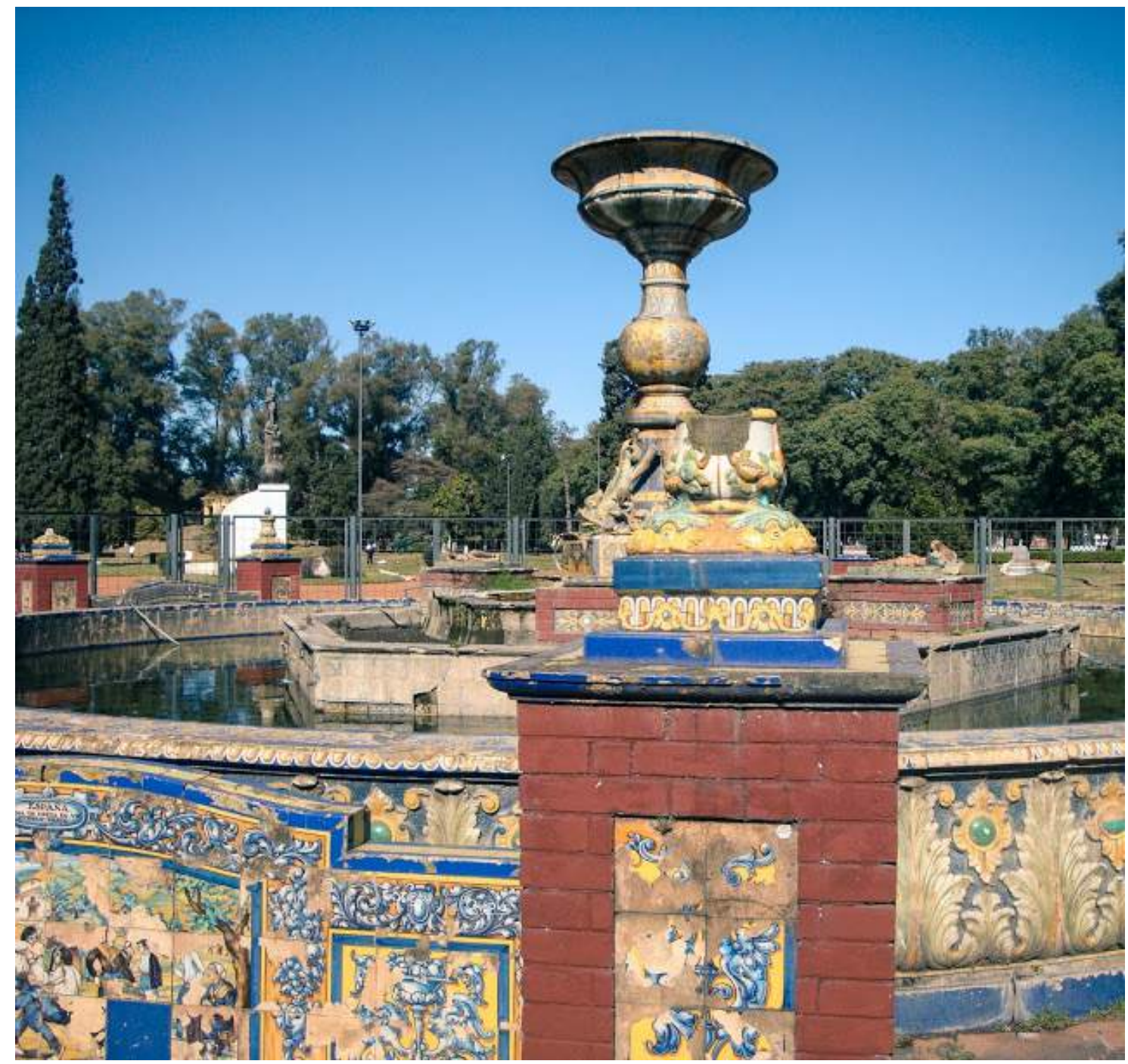

Fuente: Vista de El Rosedal desde la fuente.

\section{La cerámica como corazón de la hispanidad}

La cerámica esmaltada ocupa un lugar privilegiado como expresión de la cultura hispánica. Resultado, aparentemente, de un hallazgo casual de los árabes en su intento de imitar la porcelana china, se expandió a toda Europa desde España luego de la dominación berebere. En su desarrollo se pueden distinguir por lo menos cuatro fases en las que los sitios a los que el cónsul Sierra solicitó el envío de un proyecto de fuente -Menises, Triana y Talavera- tuvieron particular protagonismo.

En un principio, bajo franca influencia de los artesanos árabes, predominó la ejecución de losetas cocidas con las que se revestían los muros articulando piezas de distinto color y forma 
(alicatado). Luego, con las técnicas de la cuerda seca (líneas en relieve) o aristas (perfiles rehundidos con matriz metálica), se confeccionaron azulejos de bulto donde se aplicaban los colores en diseños de rígida geometría. Los centros más importantes fueron Teruel en Aragón, Málaga, Triana en Sevilla, Paterna y Manises en Valencia, esta última sede de una floreciente industria tras la compra en 1308 del yacimiento de terra de cànter por el consejero real Pere Boïl que promovió una técnica de esmaltado con reflejos dorados que hizo famosas a sus mayólicas más allá de los Pirineos.

Un cambio radical se produjo en el siglo XVI con la incorporación de técnicas renacentistas italianas. Llamadas de superficie plana, suponían el calco sobre varias losetas previamente secadas de escenas históricas o pastoriles copiadas de algún grabado; éstas se policromaban y cocían para fijar los colores, para luego barnizarse y volverse a cocer. Ejecutadas a mano alzada, liberadas de los esquemas geométricos mudéjar, las escenas recurrían a medios propios de la pintura como la perspectiva y el claroscuro. El proceso comenzó en Triana con la instalación de Nicoloso Pisano, para luego trasladarse a Talavera donde el maestro flamenco Ian Floris había introducido técnicas de Delf que se usaron para decorar el Alcázar en Madrid en 1536. Luego de adoptar la técnica italiana, con perfiles en azul, nubes acaracoladas y árboles de copa escalonada, los alfares de Talavera se transformaron en proveedores de la casa real, suministrando la vajilla y los azulejos para El Escorial, y recibiendo impulso definitivo tras la prohibición, en 1601, del uso de oro o plata en colgaduras, decoraciones o enseres. Su influencia se trasladó a América donde, a principios del siglo XVII, comenzó en Puebla el desarrollo de una industria acoplada a la de Talavera.

Este florecer se opacó en el siglo XVIII en coincidencia con la llegada de los borbones, con un nuevo viraje de la moda, esta vez hacia temas franceses que tuvieron como centro la ciudad de Alcora (Valencia), donde el Conde de Aranda convocó a artífices italianos, holandeses y galos quienes, bajo la guía del maestro Eduardo Roux, incorporaron a la decoración temas frívolos, guirlandas y florecillas. La crisis se agravó con la invasión napoleónica que provocó la casi desaparición de los alfares, algunos de los cuales sobrevivieron acentuando el carácter popular de una producción ya desacreditada.

Sobre este terreno yermo actuó Juan Ruiz de Luna "resucitando el arte de la cerámica" según sus publicistas, al recuperar y repetir técnicas y temas tradicionales. En realidad esta vuelta al pasado de la cerámica, casi como souvenir, ya había comenzado a mediados del siglo anterior a través de Charles Pickman y su empresa fundada en el antiguo monasterio de la cartuja de Sevilla que le valió ser nombrado proveedor de la Casa Real. En los años siguientes, y con la llegada del ferrocarril, se instalaron nuevas fábricas en Manises y su cerámica con reflejos metálicos fue premiada en exposiciones internacionales al tiempo que los arquitectos del 


\section{Ana María Rigotti}

modernisme català (Lluis Domenech e Montaner, Antonio Gaudi) la incorporaban a sus obras. Con marcado sesgo industrial, sus prensas eléctricas permitieron reducir el espesor de los azulejos y aumentar las exportaciones a Europa y América del Sur. Mientras tanto, en Talavera, Juan Niveiro estableció el alfar El Carmen con operarios traídos de Manises. Con él pretendió asociarse Juan Ruiz de Luna.

Nacido en Noez, provincia de Toledo, en 1863, Juan Ruiz de Luna se había iniciado como pintor y decorador en Talavera junto con sus hermanos hacia 1880. Luego de la muerte de ellos durante una epidemia de cólera, siguió trabajando pintando cuadros costumbristas y restaurando retablos. En estas circunstancias estableció amistad con el Marqués de Comillas gracias a quién viajó a Roma en 1894. De vuelta a Talavera trabajó como fotógrafo y entre sus trabajos se destaca una colección de postales sobre la cerámica tradicional de la región. En 1907 conoció al artista cordobés Enrique Guijo Navarro, otro artista interesado en este arte tradicional, y ante el fallido intento de asociarse al mencionado Niveiro para producir cerámica estilo renacentista, se unieron para crear un alfar propio con el fin de hacer renacer la cerámica artística de Talavera, cantada y retratada por poetas y pintores del Siglo de Oro, a través de una recuperación consciente de los modelos tradicionales.

Los hornos del alfar Nuestra Señora del Prado fueron construidos siguiendo modelos árabes en ladrillo refractario; compraron moldes y prensa de una fábrica abandonada de Madrid; realizaron múltiples experimentos para recuperar técnicas antiguas en la elaboración de pastas, pigmentos, esmaltes y modos de cocción manteniendo niveles mínimos de industrialización hasta su cierre en 1961. Por falta de operarios capacitados, debieron dar clases de dibujo y pintura en la escuela El Bloque que fundaron inspirados en las teorías reformistas de Karl Krause.

Imagen 6

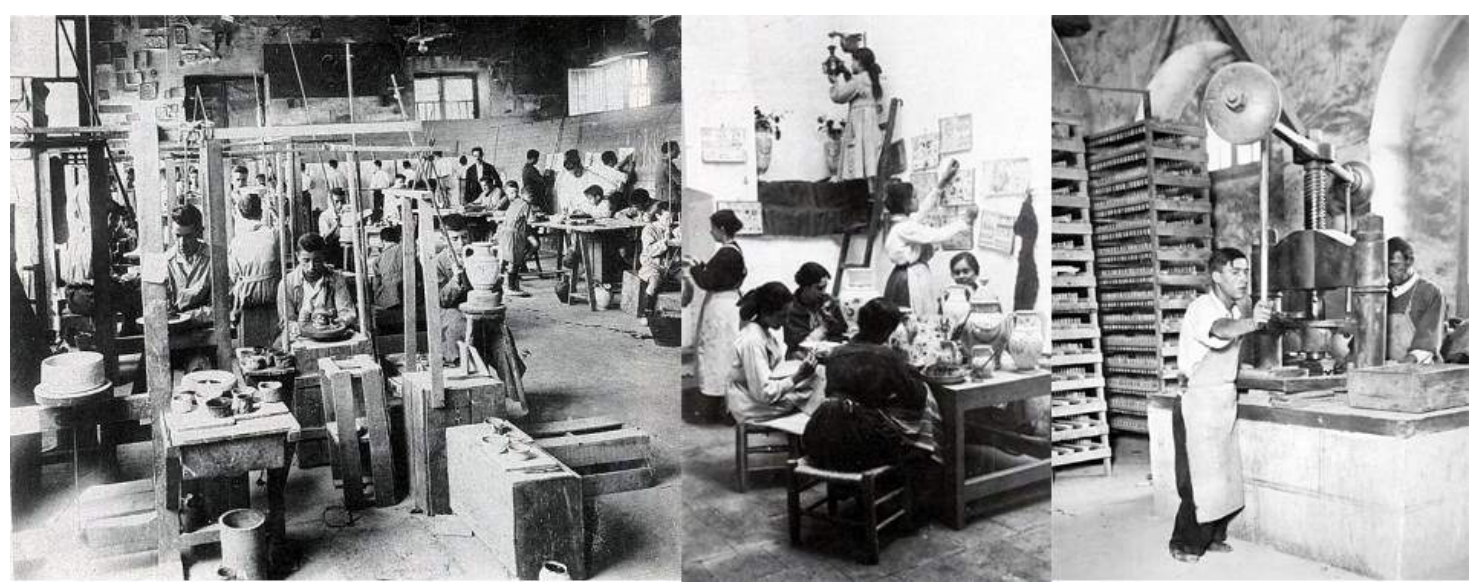

Fuente: Escenas del alfar de Ruiz de Luna: prensa de azulejos, taller de hombres, taller de mujeres, cocción de un jarrón de gran porte. Wikicommons Ruiz de Luna. 
Esta recuperación historicista de las artes y artesanías nacionales, que equiparaba lo auténtico con lo bello, generaba simpatías entre intelectuales y artistas. Así fue como Ruiz de Luna estableció vínculos con Francisco Tárrega, Joaquín Sorolla, Ignacio Zuloaga, incluso con José Ortega y Gasset. Fue la colección de cerámicas antiguas de Platón Páramo la que le sirvió de inspiración; incluso comenzó él mismo la formación de un museo propio que alcanzó las 600 piezas que se exponían dentro de un gabinete integrado al alfar. Las que más le atraían eran las piezas italianizantes del manierismo español que ofrecían mayores dificultades de ejecución, en particular los paneles, altares y retablos del siglo XVI y XVII. Las piezas polícromas producidas por el alfar no sólo recuperaban imágenes religiosas, sino figuras de animales y escenas de caza. Se caracterizaban por un gusto por lo brillante y decorativo, por la perfección del dibujo, la nitidez del vidriado y la vibración del colorido en cuya paleta se destacaban los tonos verdes que le otorgaban identidad (Lopez Fernandez, 2015, p. 139-141).

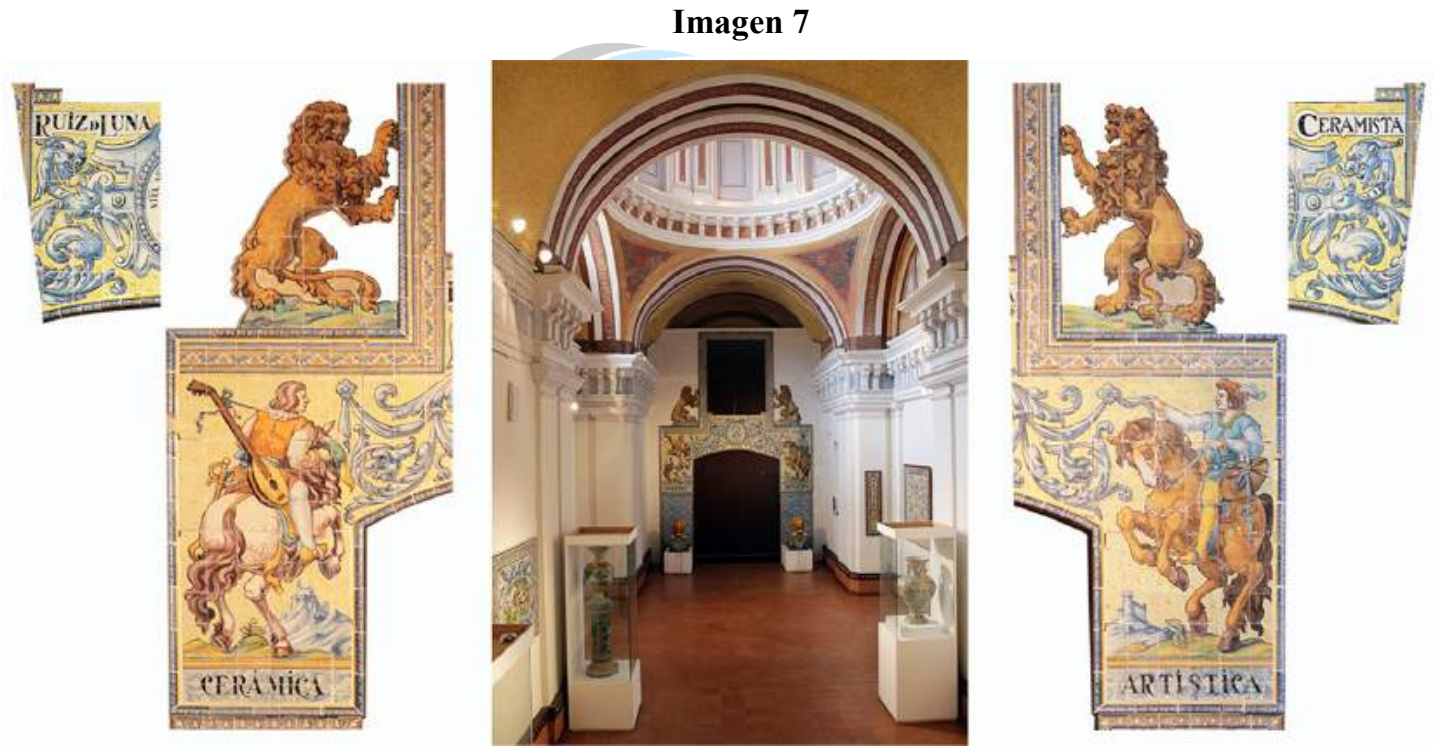

Fuente: Fachada del alfar Nuestra Sra del Prado, Talavera (1914) Wikicommons Ruiz de Luna 


\section{Ana María Rigotti}

\section{Imagen 8}

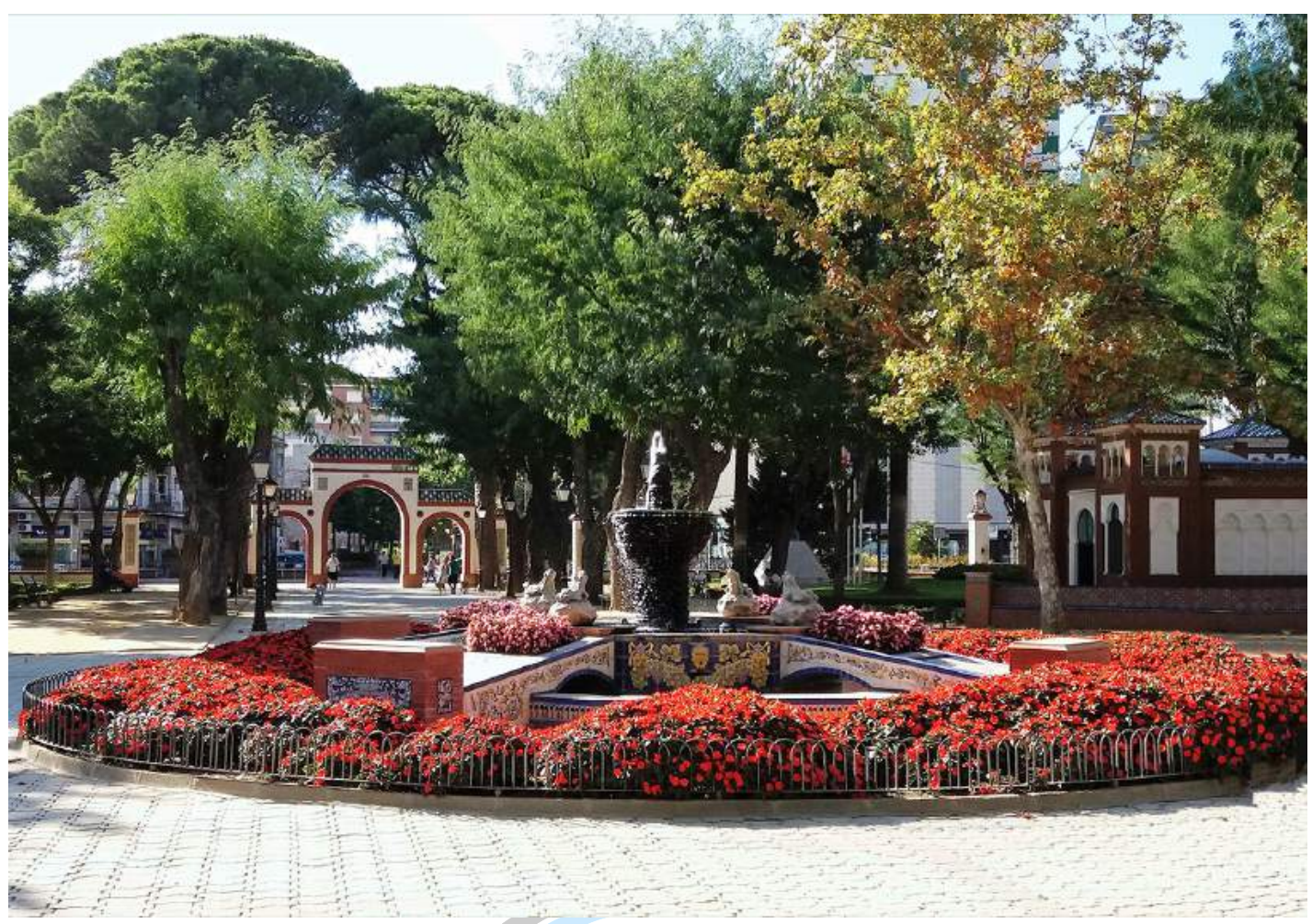

Fuente: Fuente monumental de las Ranas, Talavera (1924). Wikicommons Ruiz de Luna.

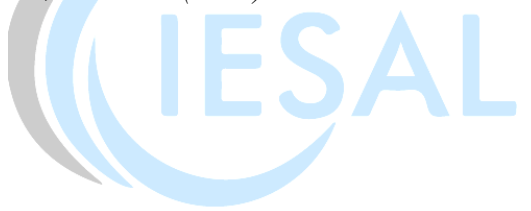

\section{Imagen 9}
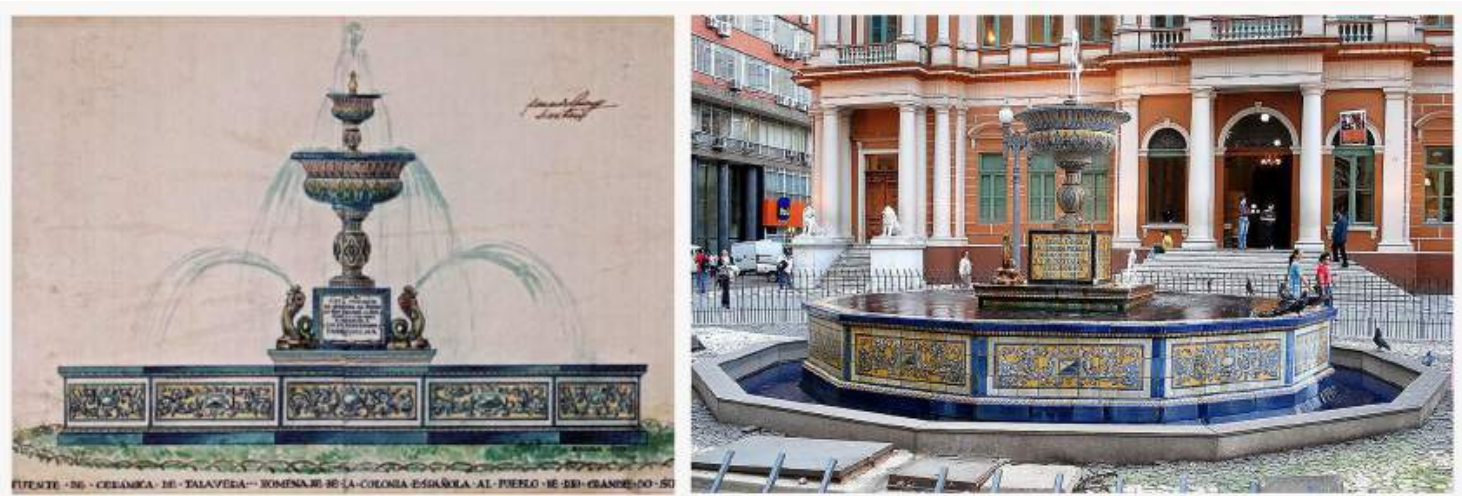

Fuente: Fuente en honor del Primer Centenario de Farroupilha en Porto Alegre (1935). Wikicommons, Ruiz de Luna.

El alfar comenzó a producir en septiembre 1908. Al año siguiente, Ruiz de Luna viajó a Santander para supervisar el revestimiento de un pórtico con una caja de muestras que ofreció en los bazares de distintas ciudades del norte descubriendo las dificultades de comercializar, 
para menaje, piezas de tan alto costo de producción. Discusiones sobre la conveniencia de ofrecer los productos en Estados Unidos habrían provocado la disolución de la sociedad quedando el alfar en su sola propiedad y delegando en su yerno, Francisco Arroyo Santamaría, la dirección artística con un catálogo con temas del Renacimiento Español. Se concentraron entonces en obras de decoración, especialmente en retablos y en el revestimiento de fachadas, zaguanes y escaleras que alcanzaron gran difusión en la arquitectura de la naciente burguesía en la segunda década del siglo, en particular en la Gran Via de Madrid. El éxito de la empresa fue considerable y entre sus obras se destacan las fachadas del Teatro Victoria (1913), el portal del alfar en la que se representa el trote de dos caballos y dos juglares (1914), la Fuente de las Ranas (1924), todas en Talavera. En la Exposición Iberoamericana de Sevilla (1929) presentaron retablo de Santa Leocadia de $6 \mathrm{~m}$ altura, la Fuente de los Tritones arrimada al edificio de Castilla la Nueva y un banco representativo de Toledo en la Plaza España, recibiendo el Gran Premio y Medalla de Oro. Pero sus historiadores no dudan en afirmar que la Fuente Monumental para Rosario (1928), y luego los zócalos, vestíbulos y andenes para el subte de Buenos Aires (1930-1934), ocupan un lugar destacadísimo.

El reconocimiento como empresario de Ruiz de Luna fue total. Recibió la Medalla de Oro en Exposición de Artes Aplicadas y Decorativas de 1911, el Diploma de Honor en Exposición de Bellas Artes de 1920, fue nombrado Académico de Bellas Artes y Ciencias Históricas de Toledo en 1923, el rey Alfonso XIII le otorgó la Cruz de Caballero de la Orden Civil en 1925 y ganó Medallas de Oro en las exposiciones de Filadelfia (1927) y Monza (1930).

\section{Una obra excepcional}

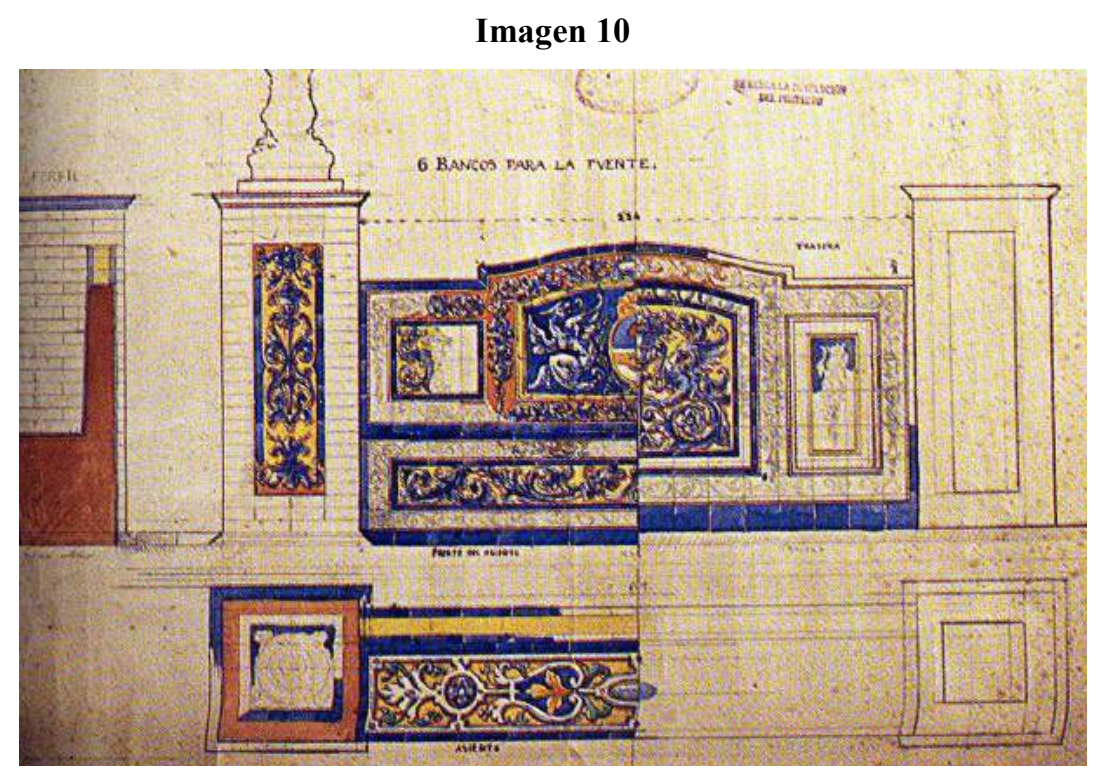

Fuente: Boceto de Juan Ruiz de Luna Arroyo para bancos de la fuente en Rosario (1927). Archivo Amparo Ruiz de Luna reproducido en Tesis C. López Fernández p. 341. 


\section{Ana María Rigotti}

Habría sido la escala y la monumentalidad del diseño de la fuente, además de "la elegancia" de la cerámica de Talavera, las que motivaron la selección de esta propuesta. Su precio fue de 50.000 pesetas abonadas al cerrar el contrato y un monto igual el 27 de mayo de ese mismo año. El encargo incluía un portal para El Rosedal (no identificado) y otra fuente para el jardín del Hospital Español. Las piezas sumaron un volumen de $55 \mathrm{~m} 3$, embalado en 570 cajas que pesaron 16 toneladas. Salieron de la fábrica el 6 de junio de 1928.

La fuente se desarrolla en un diámetro de $18 \mathrm{~m}$, alcanza $6 \mathrm{~m}$ de altura y está conformada por 8.000 piezas. Revestida totalmente en mayólicas talaveranas, consta de 3 pilones superpuestos: la taza principal y dos más que rematan en el tazón superior de pilón central. La columna cuenta con un basamento de surtidores y la sostienen dos amorcillos. A la altura del segundo pilón, se ubican los leones, donde originariamente se había pensado un paso de césped para flores típicas de la Península: claveles y geranios. El diseño pertenece al mencionado Francisco Arroyo Santamaría. El primer pilón está rodeado por un piso de planta hexagonal en cuyos límites se ubican seis bancos con motivos costumbristas en su respaldo, obra de Juan Ruiz de Luna, hijo, cuya originalidad se compara a aquella del banco premiado en la Exposición de Sevilla. La ejecución supuso varios desafíos técnicos, en particular las piezas del pilón, la columna central y la taza superior que debieron rehacerse varias veces debido a que se rajaba el modelado durante la cocción.

\section{Imagen 11}

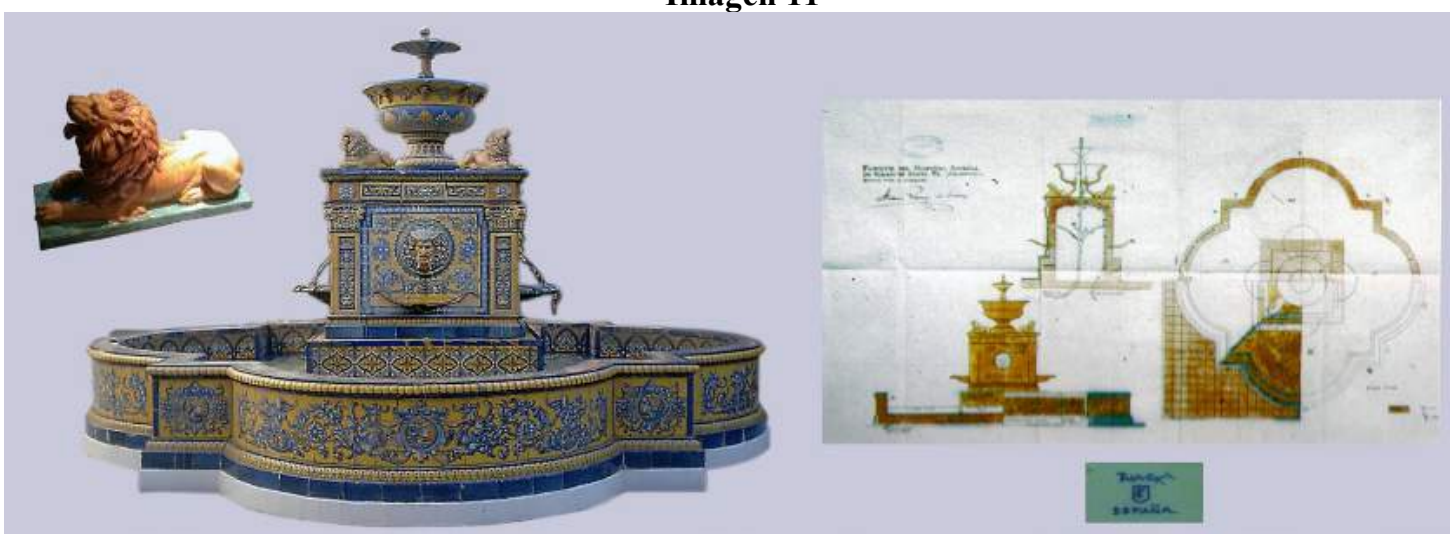

Fuente: Fuente para el Hospital Español. Wikicommons Ruiz de Luna. 


\section{Imagen 12}
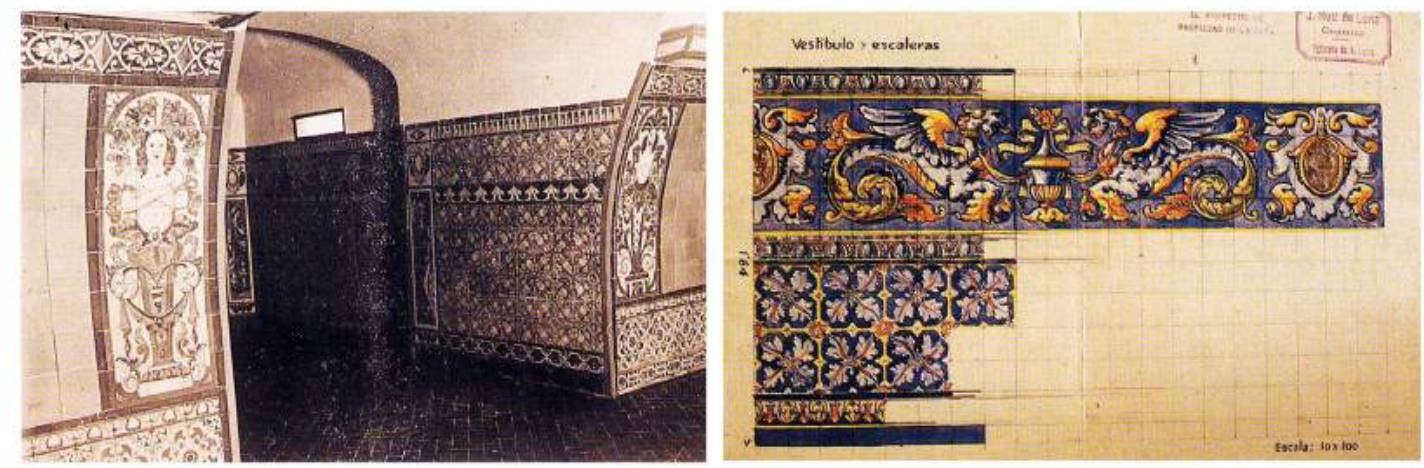

Fuente: Boceto de Francisco Arroyo para el subterráneo de Buenos Aires en Fondo Ruiz de Luna reproducido en tesis M del C. López Fernández fig. 133.

En la fuente predominan los verdes, azules y verdes y, además del atractivo del modelado y anatomía de los seres fantásticos, leones y peces, se destacan las perspectivas y disposición en escorzo de las distintas figuras en los bancos con las que se reproducen escenas de danzas y costumbres populares.

\section{Inauguración y después}

Las piezas llegaron al puerto de Buenos Aires el 12 septiembre 1928, previendo su inauguración con gran fasto para el Día de la Raza, celebración establecida por Hipólito Yrigoyen en 1917 que, en el marco político e ideológico que hemos sintetizado más arriba, tenía particular relevancia para el nuevo embajador de Maeztu. Sin embargo, una serie de demoras en la aduana decidieron la postergación del festejo para el 7 de julio del año siguiente.

Además del embajador, estuvo presente el gobernador Pedro Gómez Cuello. En el día anterior hubo un banquete en honor de Maeztu por parte de la colectividad española en el bar Cifré, con baile posterior en el Club Español, y ese día hubo un banquete oficial en el Palacio Municipal. Otra de las actividades de Maeztu fue visitar la sede del Banco Monserrat, empresa de otro de los miembros de la comisión Pro- Fuente.

La inauguración fue la ocasión para un duelo de discursos hiperbólicos, cuyo optimismo esperanzado resulta algo disonante a nuestros oídos actuales. En nombre de la colectividad habló Angel García, cuya nueva sede de la tienda departamental La Favorita acababa de inaugurarse dos meses antes. "Entregamos a la ciudad esta fuente monumental laborada con tierra de España, por mano de artistas españoles. Queremos los españoles residentes en esta gran urbe asociarnos al júbilo general del pueblo viril que, en solo 200 años de existencia, de una modesta capillita sobre la barranca se ha convertido en la ciudad populosa con medio millón de 


\section{Ana María Rigotti}

habitantes, con industrias y fábricas y talleres y comercios y vida propia, con uno de los más importantes puertos del mundo y con una ruta abierta hacia el porvenir llena de promisorias esperanzas". El intendente Tobias Arribillaga contestó "Nada tienen los españoles que agradecernos porque al estrecharnos cotidianamente en el ceñido abrazo del trabajo somos como dos hermanos que se apoyan mutuamente para llevar siempre más allá el agradecimiento de ambos pueblos que unidos pueden realizar las grandes obras que la humanidad necesita y espera de ellos". De Maeztu, por su parte, hizo valer sus dotes de orador siendo "cada párrafo subrayado por el aplauso de los oyentes". Habló de España como madre gestadora de naciones, e hizo un canto de alabanza a los valores morales que condicionan el espíritu hidalgo de la raza hispanoamericana, concluyendo "y sea ésta, fuente de salud, de frescura y de bienaventuranza para vosotros". ${ }^{7}$

El deterioro de la fuente fue gradual e inexorable: piezas faltantes o rotas, corrosión de la estructura en hierro fundido, destrucción de la cañería de alimentación de los chorros de agua, hundimiento en el barro de los solados y del cimiento de los bancos. A mediados del año 2016 y junto a otras obras de mejoramiento de El Rosedal, se decidió restaurarla. Luego de dos 1lamados fallidos, fue adjudicado a la empresa Melting SRL a mediados de 2017. A medida que las obras avanzaron, como suele ser el caso, se fueron descubriendo nuevas fallas y el presupuesto necesario se duplicó hasta alcanzar los casi seis millones de euros. Los monumentos, en particular las obras de arte que engalanan nuestros espacios públicos, suelen ser valiosos y costosos; únicos no sólo en su concepción sino en sus técnicas, lo que implica fuertes desafios al intentar consolidarlos y recuperarlos.

\section{Bibliografia}

Alvarez, J. (1981). Historia de Rosario. Universidad Nacional del Litoral [Reimpresión 1939].

Ballesteros Gallardo, Angel (1983). Cerámica de Talavera: tres tiempos para una historia. IPIET, Serie Temas toledanos, 33.

Barriera, D. (2013). "Justicias rurales: el oficio de Alcalde de la Hermandad entre el derecho, la historia y la historiografía (Santa Fe, gobernación del Rio de la Plata, siglos XVII a XIX)"”. Andes, 24; 1; 1-2013: 1-31.

Berjman, S. (2006). "Una Mirada a los espacios verdes públicos de Buenos Aires durante el siglo XX. Arquilectura 08, Universidad Católica de Colombia.

Camarasa, S. (1928). "Un triunfo del arte español. La fuente de cerámica más grandiosa del mundo", $A B C$, 5-agosto.

${ }^{7}$ La Capital, 3, 7 y 8 julio 1929. 
"Una joya del Segundo Renacimiento Español en Rosario. La Fuente de los Españoles"

Conde, J. L. (2020). Carta al Presidente de la Federación de Asociaciones Españolas de las Provincia de Santa Fe Sr. Juan Luis Martínez del 10 diciembre.

de Amador, H.F. (1926). "Significado estético de la nueva casa de humanidades". Plus Ultra 11,1926 117: 14,15.

de Marco, M. A.; Ensinck, O. (1978). Historia de Rosario. Museo Histórico Provincial Dr. Julio Marc.

El Eco de España (1928). "La ofrenda de los Españoles a la Ciudad de Rosario", El Eco de España, Año XII, No 621.

Gerchunoff, A. (1929). "Ramiro de Maeztu”, Plus Ultra 141929 162:13.

Gonzalez Calleja, E. (2007). "El hispanismo autoritario español y el movimiento nacionalista argentino: balance de medio siglo de relaciones políticas e intelectuales (1898-1946)". Hispania. Revista Española de Historia, vol LXVII, nº 226, mayo agosto: 599-642

Granziera, P. (2014). "The Art of Gardening in New Spain: Spanish Heritage in Mexican Gardens". Garden History, vol 42, № 2: 178-200.

Hurley Molina, M.I. (1989). Talavera y los Ruiz de Luna. Talavera de la Reina: Publicaciones del Instituto Provincial de Investigaciones y Estudios Toledanos.

Leoni, D.; Macioci, V.; Martínez Castillo, P. (2017). “Cerámica de Talavera en España y México". 3ras Jornadas estudiantiles de Investigación en disciplinas artísticas y proyectuales. Facultad de Bellas Artes, UNLP.

Lopez Fernandez, M. C. (2015). Técnica y estética de la cerámica de Talavera de la Reina. Recursos iconográficos. Tesis Doctoral Universidad Complutense de Madrid.

Martínez Nespral, F. (2018). "Migraciones, interculturalidad, exilio y arquitectura. Cerámica española del siglo XVII en Túnez y América, un encuentro transatlántico”. AREA - Agenda De Reflexión En Arquitectura, Diseño y Urbanismo, 25 (2): 1-14.

Martini, O.R. (2013). "Ramiro de Maeztu en la Argentina. La gestación de la doctrina de la Hispanidad entre el catolicismo y el nacionalismo argentino". La Razón Histórica. Revista hispanoameriana de Historia de las Ideas. $\mathrm{N}^{\circ}$ 24: 9-12.

Megías, A.; Prieto, A.; Martín M. P.; Múgica, M. L.; Montini, P. (2014). Las batallas por la identidad. Editorial Municipal de Rosario.

Nuñez Seixas, X. M. (2017) “ ¿Negar o reescribir la hispanidad? Los nacionalismos subestatales ibéricos y América Latina, 1898-1936". Historia mexicana vol.67, nº 1, julio/setiembre.

Plus Ultra (1925a) “El Palacio de la Caja de Ahorro Postal”. Plus Ultra 101925 107: 37.

Plus Ultra (1925b) "El nuevo santuario del camarín de Nuestra Señora del Rosario". Plus Ultra 101925 114: $26-27$

Plus Ultra (1929).-“Influencia española en nuestra arquitectura” Plus Ultra 14-1929 162: 13-14 


\section{Ana María Rigotti}

Salverría J. M. (1926). "La fuente de las Cibeles”. Plus Ultra 11-1926 117:36.

Suero, P. (1925a) "El estilo incaico en el mueble”. Plus Ultra 10:1925 109:14

Trilles Mateu, M. C. (2014). "La cerámica de Manises y Paterna S.XIV-XV: els socarrats".

Forum de recerca 19: 191-207.

Wikimedia Commons. Category Juan Ruiz de Luna.

Recepción: 20/07/2021

Evaluado: 27/09/2021

Versión Final: 29/11/2021 